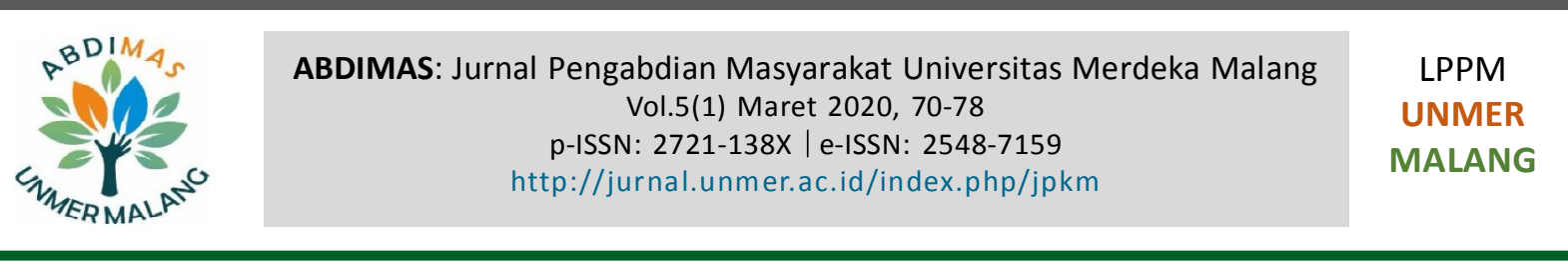

\title{
Pengenalan dan Penerapan Pembangkit Listrik Tenaga Surya di Desa Muara Kilis Kabupaten Tebo Jambi
}

\author{
Yani Prabowo, Suwasti Broto, Gunawan P. Utama, Grace Gata, Yuliazmi \\ Departemen Sistem Komputer, Fakultas Teknologi Informasi, Universitas Budi Luhur \\ Jl. Ciledug Raya, DKI Jakarta, 12260, Indonesia
}

\begin{abstract}
ARTICLE INFO:
Received: 2019-08-10

Revised: 2019-12-14

Accepted: 2020-02-09
\end{abstract}

\section{Keywords:}

Community service;

DC installation systems;

Solar panels

\begin{abstract}
Community service activities were carried out to introduce solar panel technology to the Suku Anak Dalam village community in Muara Kilis Jambi, where the village had some electricity that had not yet been electrified by PLN. Because PLN has not reached the electricity network, the general public uses generators with fuel as a motor for generating electricity. The use of fuel, especially in rural areas can be said to require expensive costs for operations coupled with the cost of engine maintenance. The use of solar panels is one of the easy and inexpensive alternatives to get electricity. The installation system that is applied is the DC system will make more economical and low-cost installation. With the implementation of this service, one month is enough to meet the electricity needs in the household for every night. The residents can do the installation well and can analyze the electricity needs to be used. In addition to installing the panels, they have understood the laying of the panels according to recommendations using the PV Power System software.
\end{abstract}

(C) 2020 Published by University of Merdeka Malang. This is an open access article distributed under the CC BY-SA 4.0 license (https://creativecommons.org/licenses/by-sa/4.0/)

How to cite: Prabowo, Y., Broto, S., Utama, G. P., Gata, G., \& Yuliazmi. (2020). Pengenalan dan Penerapan Pembangkit Listrik Tenaga Surya di Desa Muara Kilis Kabupaten Tebo Jambi. Abdimas: Jurnal Pengabdian Masyarakat Universitas Merdeka Malang, 5(1), 70-78. https://doi.org/10.26905/abdimas.v5i1.3555

\section{PENDAHULUAN}

Listrik sudah menjadi kebutuhan setiap manusia yang hidup dijaman sekarang, bermacam cara usaha dilakukan untuk mendapatkan listrik. Kebutuhan listrik sebagian besar disuplai oleh perusahaan listrik negara (PLN) tetapi belum semua wilayah di Indonesia mendapatkan jaringan listrik tersebut, sedangkan permintaan energi listrik setiap tahun terus meningkat. Berbagai upaya telah dilakukan oleh pemerintah atau masyarakat sendiri dengan membangun pembangkit secara mandiri dari berbagai macam sumber

Corresponding Author:

Yani Prabowo:

Tel. +62 215853753

E-mail: yani.prabowo@budiluhur.ac.id 


\section{Pengenalan dan Penerapan Pembangkit Listrik Tenaga Surya di Desa Muara Kilis Kabupaten Tebo Jambi}

Yani Prabowo, Suwasti Broto, Gunawan P. Utama, Grace Gata, Yuliazmi

energi. Kelistrikan di rumah tinggal rata-rata disuplai oleh PLN sedangkan belum semua wilayah terjangkau oleh PLN, maka dibutuhkan pembangkit pendukung PLN dengan bahan bakar minyak atau dengan pembangkit listrik energi terbarukan seperti dari tenaga angin, air, atau matahari. Pembangkit listrik energi terbarukan bisa disesuaikan dengan lokasi yang memiliki potensial yang baik. Pembangkit alternatif terbarukan yang cocok dengan keadaan geografis adalah PLTS (Pembangkit Listrik Tenaga Surya). Letak Indonesia berada pada daerah khatulistiwa, maka wilayah Indonesia akan selalu disinari matahari selama 10 sampai dengan 12 jam dalam sehari. Data Ditjen Listrik dan Pengembangan Energi pada tahun 1997, kapasitas terpasang listrik tenaga surya di Indonesia mencapai 0,88 MW dari potensi yang tersedia 1,2 $\mathrm{x}$ 109 MW (Widodo et al., 2010).

Pemanfaatan energi terbarukan diantaranya dengan memanfaatkan tenaga radiasi matahari menggunakan sel surya sebagai pengkonversi energi matahari menjadi energi listrik yang kita kenal dengan Pembangkit Listrik Tenaga Surya (PLTS). Cahaya matahari terdiri atas foton atau partikel energi surya yang dikonversi menjadi energi listrik. Energi yang diserap oleh sel surya diserahkan pada electron sel surya untuk dikonversi menjadi energi listrik (Suriadi \& Syukri, 2010). Pemanfaatan energi surya juga membutuhkan biaya pemasangan yang relatif cukup besar, sehingga diperlukan perhitungan perencanaan dan analisis ekonomi dengan mengetahui kelayakan investasi proyek PLTS tersebut (Winardi, Nugroho, \& Dolphina, 2019).

Kegiatan ini merupakan pengabdian masyarakat yang diterapkan di wilayah Desa Muara Kilis, Kabupaten Tebo Jambi, karena ada sebagian wilayah belum teraliri listrik dari PLN. Sebagian masyarakat menggunakan genset sebagai pembangkit listrik. Setiap operasional dalam satu malam, bisa menghabiskan 7 liter sampai 10 liter bahan bakar bensin dengan harga BBM mencapai Rp10.000 ditingkat pengecer. Secara ekonomi tentu sangat memberatkan masyarakat itu sendiri. Kegiatan ini dilakukan di Gedung Pusat Informasi Suku Anak Dalam Muara Kilis, yang menjadi lokasi percontohan penerapan instalasi panel surya. Gedung tersebut sering digunakan untuk kegiatan pertemuan oleh warga desa Muara Kilis terutama pada malam hari dan belum teraliri listrik PLN.

Tujuan diadakan pengabdian pada masyarakat ini adalah memperkenalkan teknologi pembangkit listrik tenaga surya sehingga masyarakat tidak menggantungkan penggunaan BBM untuk pembangkit listrik. Manfaat dari kegiatan ini diharapkan membantu perekonomian warga desa, melalui pengunaan panel surya. Masyarakat tidak perlu lagi mengeluarkan biaya untuk mendapatkan energi listrik dalam jangka panjang.

Setelah masyarakat mengetahui dan memahami manfaat dari panel surya, yang menjadi kendala lain adalah bagaimana masyarakat dapat membeli panel surya tersebut, karena untuk membeli bahan bakar minyak dapat dibeli dengan uang yang seadanya. Keadaan perekonomian warga Desa Muara Kilis adalah umumnya petani karet dan petani sawit yang sebagian besar adalah warga Suku Anak Dalam dan warga transmisgrasi. Pendapatan mereka setiap hari tidak menentu tergantung terutama petani karet, jika musim panas hasil karet yang didapat bisa banyak tetapi harga pasaran rendah. Sedangkan petani sawit jika sedang musim hujan sangat sulit untuk memanen kelapa sawit karena medan yang cukup berat. Untuk mengeluarkan uang sebesar Rp 70.000; adalah hal yang sangat memberatkan apalagi harus setiap hari. Maka dengan kegiatan pengabdian pada masyarakat ini dapat memberikan penjelasan kepada warga untuk mendapatkan sumber energi yang murah. Disamping itu kegiatan ini juga untuk memperkenalkan lembaga pendidikan Universitas Budi Luhur kepada masyarakat melalui program tridharma. 


\section{ABDIMAS: Jurnal Pengabdian Masyarakat Universitas Merdeka Malang}

Volume 5, No 1, Maret 2020: 70-78

Pemanfaatan tenaga matahari untuk pembangkitan listrik sudah dilakukan cukup lama namun penerapannya masih terbatas pada sistem berdaya kecil atau yang lebih dikenal dengan Solar Home System (SHS). SHS ini biasanya merupakan bantuan pemerintah yang diberikan secara subsidi dan masyarakat pedesaan menggunakannya sebagai sarana penerangan di malam hari untuk mengganti lampu minyak tanah. Dalam konteks ini terlihat bahwa pendekatan yang digunakan bersifat top-down sehingga selama ini perkembangan SHS sangat tergantung pada program pemerintah dan sejauh ini kontribusi energi listrik surya nasional masih sangat kecil (Kumara, 2010).

Sistem modul surya dengan skala 50-100 WP (Watt Peak) dapat menghasilkan listrik sebesar 150300 Wh. Lebih baik menggunakan sistem DC (Direct Current) untuk menghindari losses dan self consumption akibat digunakannya inverter. Karena sistemnya yang kecil dan dipasang secara desentralisasi, satu rumah satu pembangkit sehingga tidak memerlukan jaringan distribusi atau bisa disebut jaringan offgrid tidak terhubung kemanapun (Rif'an et al., 2012). Penggunaan PLTS berdampak terhadap kehidupan ekonomi masyarakat, yang dinilai dari adanya peningkatan ekonomi masyarakat. Hal tersebut dibuktikan dengan penggunaan SHS sangat bermanfaat dan membantu masyarakat di malam hari terutama pelajar dan ibuibu yang memiliki anak kecil, serta membantu warga desa Soko Kembang yang merupakan desa terpencil yang sebelumnya mengandalkan penerangan dari lampu minyak dan genset sewa (Musyahar, 2019). Menurut Ruby, Yusman, \& Aziz (2008) bahwa mesin genset memiliki biaya awal yang murah dan mudah dalam instalasi. Akan tetapi, sistem genset dianggap tidak efisien dan memerlukan biaya operasional serta biaya perawatan yang mahal. Disamping itu tidak mampu menyimpan energi listrik apabila keluaran genset melebihin permintaan, sementara biaya perawatan menjadi mahal ketika genset dioperasikan pada kapasitas level rendah dari daya maksimumnya untuk periode waktu yang sama. Contohnya untuk menyalakan lampu 10 watt dan 100 watt dengan menggunakan genset yang sama, akan mengkonsumsi jumlah bahan bakar yang sama besarnya dan tidak semua kemampuan energi dari genset terpakai (Ruby et al., 2008).

Sebagian besar Panel Surya 12 Volt menghasilkan tegangan keluaran sekitar 16 sampai 20 volt DC, rata-rata $\pm 17,2 \mathrm{~V}$ tergantung juga intensitas cahaya yang diterima. Tegangan yang dihasilkan tersebut tidak bisa langsung dimasukkan kedalam baterai $12 \mathrm{~V}$ karena dapat merusak sel pada baterai, maka diperlukan pengaturan tegangan solar charge controller yang mengatur tegangan masuk ke baterai sekitar 13-14,8 volt (Purwoto et al., 2017).

Energi listrik yang dihasilkan panel surya disimpan pada baterai, energi listrik tersebut digunakan pada malam hari. Baterai pada sistem PLTS ini memegang peranan penting karena menyangkut daya tampung energi yang disimpan. Pengunaan baterai untuk PLTS berbeda dengan penggunaan baterai pada sistem otomotif dan ketersediaan baterai untuk PLTS saat ini sudah mudah ditemukan (Diantari, Erlina, Widyastuti, 2017).

Baterai yang dipergunakan pada PLTS mengalami proses siklus pengisian (charging) dan pengosongan (discharging), dipergunakan secara terus berulang. Kapasitas baterai dalam suatu perencanaan PLTS dipengaruhi pula oleh faktor DOD dan TCF (Alfanz, Maulana, \& Haryanto, 2015). Penelitian efisiensi panel surya sumber energi alternatif jika dibandingkan dengan penggunaan generator/ genset sebagai sumber energi untuk peralatan listrik pernah dilakukan oleh Purwoto et al. (2017), disimpulkan bahwa penggunaan genset mudah dalam instalasi tetapi mahal biaya operasional sedangkan penggunaan panel surya adalah mahal dalam biaya instalasi awal tetapi murah bahkan dikatakan minim biaya dalam operational. 


\section{Pengenalan dan Penerapan Pembangkit Listrik Tenaga Surya di Desa Muara Kilis Kabupaten Tebo Jambi}

Yani Prabowo, Suwasti Broto, Gunawan P. Utama, Grace Gata, Yuliazmi

Pemasangan panel surya terkendala hasil yang tidak maksimal, hal ini disebabkan peletakan sudut dari panel surya yang tidak tepat seperti diungkapkan bahwa daya yang dihasilkan sangat bergantung pada intensitas matahari yang diterima oleh panel surya. Intensitas radiasi matahari yang diterima oleh panel surya dapat dimaksimalkan dengan cara memasang panel surya, dengan sudut kemiringan atau slope dan sudut azimut yang tepat (Pangestuningtyas, Hermawan, \& Karnoto, 2013; Tamimi, Indrasari, \& Iswanto, 2016).

\section{METODE}

Berdasarkan masalah yang dihadapi oleh masyarakat desa tersebut adalah, mahalnya biaya operasional yang dikeluarkan untuk membeli minyak sebagai bahan bakar genset dan mahalnya perawatan genset tersebut, sebagai contoh dalam satu malam membutuhkan 7 liter bbm, harga satu liter Rp 10.000, maka dalam 1 bulan 30 hari. Dengan rumusan 7 liter $X R p 10.000 \times 30$ hari $=R p 2.100 .000$; belum termasuk biaya perawatan mesin genset. Metode yang digunakan dalam kegiatan adalah dimulai dengan sosialisasi awal kepada masyarakat mengenai teknologi panel surya, kemudian dilakukan analisa terhadap kebutuhan daya yang digunakan, dilanjutkan dengan pembangunan PLTS. Dilanjutkan dengan pengujian untuk mendapatkan hasil. Sosialisasi akhir dilakukan untuk memaparkan kepada masyarakat mengenai manfaat dan keuntungan dari penggunaan panel surya. Kegiatan pengabdian masyarakat dilaksanakan bulan Agustus 2019 di Desa Muara Kilis, Kabupaten Tebo, Jambi. Metodologi yang digunakan dalam pengabdian ini digambarkan dalam bentuk diagram alir (flowchart) yang sistematis seperti Gambar 1.

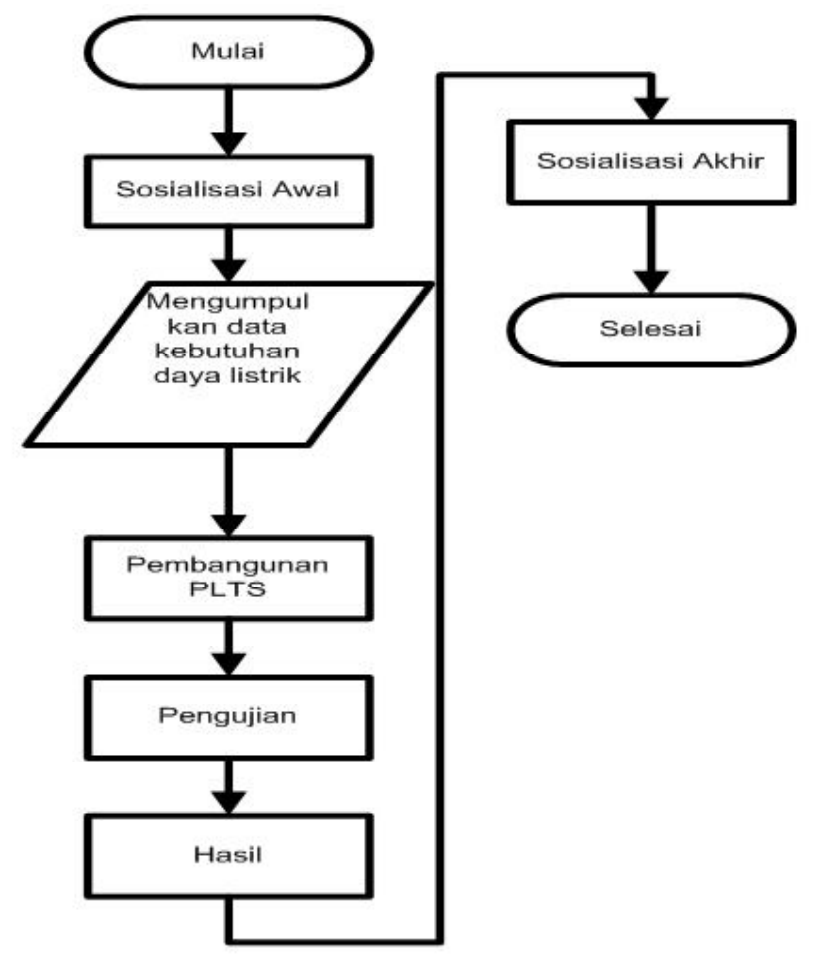

Gambar 1. Diagram alir pengabdian 


\section{ABDIMAS: Jurnal Pengabdian Masyarakat Universitas Merdeka Malang}

Volume 5, No 1, Maret 2020: 70-78

\section{Metode kegiatan}

Dalam kegiatan masyarakat dimulai dengan sosialisasi awal kepada warga bersama perangkat desa melakukan sosialiasi mengunjugi rumah warga sekaligus untuk mengumpulkan data daya kebutuhan listrik setiap rumah warga. Hal ini dilakukan untuk mendapatkan gambaran yang tepat berapa daya yang dibutuhkan dan berapa panel surya yang dibutuhkan. Tahap selanjutnya adalah melakukan pembangunan atau pemasangan instalasi panel surya di Gedung Pusat Informasi Suku Anak Dalam. Kegiatan ini melibatkan karang taruna pemuda desa dan warga sehingga setelah kegiatan ini selesai, nantinya pemuda karang taruna yang akan menjadi instalatir atau petugas pemasangan panel surya dirumah-rumah. Kegiatan dilakukan sampai sosialiasi akhir, dimana pada kegiatan tersebut diperjelas kembali teori-teori dasar mengenai kelistrikan panel surya, teknik pemasangan yang tepat dengan menggunakan bantuan software PV Power System berbasis android serta penjelasan mengenai prosedur keselamatan yang berlaku. Sehingga nantinya warga tidak sembarangan melakukan instalasi panel surya. Karena jika kaidah keamanan tidak terpenuhi maka bahaya kebakaran akan mengintai.

\section{HASIL DAN PEMBAHASAN}

\section{Hasil}

Perkiraan kebutuhan listrik untuk rumah tangga difokuskan pada penggunaan sebagai penerangan dan menggunakan instalasi listrik DC. Dalam tahap pertama adalah menghitung beban listrik yang digunakan pada malam hari. Penggunaan kebutuhan tenaga listrik disajikan pada Tabel 1.

Tabel 1. Tabel kebutuhan tenaga listrik

\begin{tabular}{lc}
\hline \multicolumn{1}{c}{ Peralatan } & Watt-jam \\
\hline Lampu Kamar 5 watt x 3 x 8 jam & 120 \\
Lampu Teras dan KM 5 watt x 4 x 11 jam & 220 \\
Televisi 30 watt x 1 x 6 jam & 180 \\
Lampu ruang tengah 10 watt x 1x 11 jam & 110 \\
\hline Total & 630 \\
\hline
\end{tabular}

Berdasarkan data penggunaan daya maka diputuskan menggunakan bateri 100 ah $12 \mathrm{v}$, solar charge controller merek make sky blue $30 \mathrm{~A}$. Rangkaian tersebut menghasilkan daya sebesar 1200 watt. Dengan daya 1200 watt maka panel surya yang dibutuhkan dengan lama penyinaran matahari rata-rata 4 jam setiap hari, maka panel surya yang digunakan dengan ukuran 200 WP. Dalam kegiatan ini semua peralatan listrik yang digunakan menggunakan arus DC 12v, sehingga tidak memerlukan inverter untuk merubah arus DC menjadi arus AC. Tabel biaya pembangunan PLTS ditampilkan pada Tabel 2.

Tabel 2. Biaya untuk pembangunan PLTS

\begin{tabular}{lcc}
\hline & Peralatan & Biaya (Rp) \\
\hline Panel surya 200 wp & 1.900 .000 \\
Baterai 12v 100ah & 1.500 .000 \\
Solar Charge Controller & 1.400 .000 \\
Lampu DC 10 buah & 250.000 \\
Kabel kabel & 750.000 \\
\hline
\end{tabular}


Instalasi panel surya dilakukan dengan memperhatikan keamanan terutama pemasangan kabel tidak boleh terbalik antara kutup positif dan kutup negatif dan memperhatikan juga kekuatan kabel yang digunakan untuk instalasi. Pada Gambar 2 adalah instalasi dasar dari panel surya.

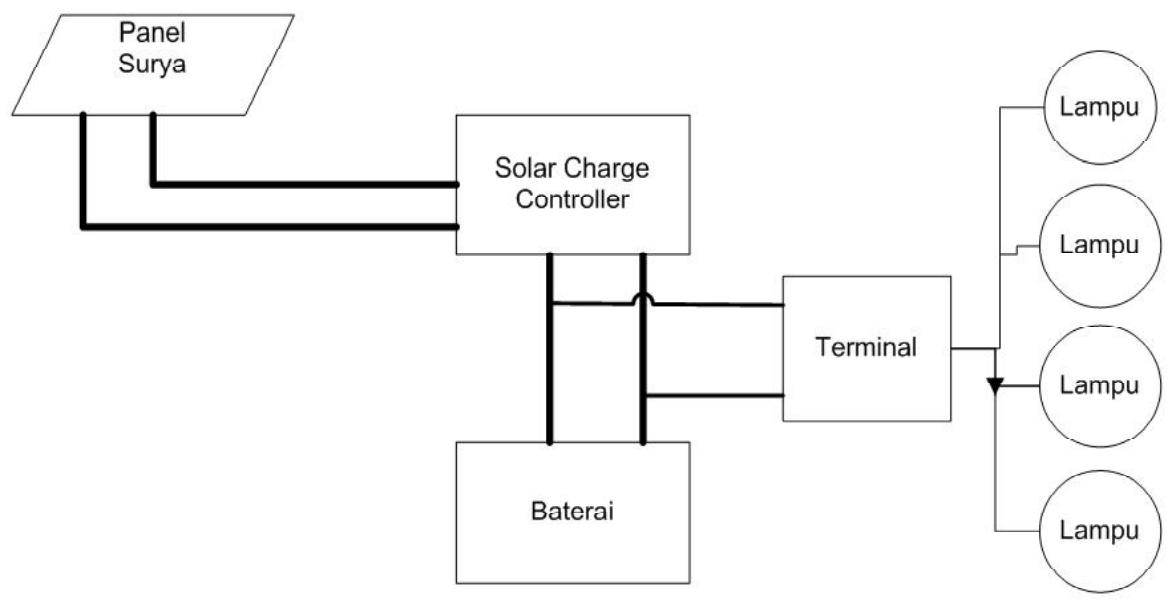

Gambar 2. Skema instalasi dasar panel surya

Penggunaan baterai dengan ukuran 100ah ini untuk mempertimbangkan bahwa tenaga di dalam baterai tidak boleh habis seluruhnya harus tersisa atau disebut dengan (SOC) sebesar 40 persen maka daya yang tersisa adalah 480 watt/jam dan daya untuk penggunaan baterai (DOD) sebesar 60 persen, maka daya yang diijinkan digunakan adalah 720 watt/jam.

Penggunaan daya pada baterai harus disisakan sebesar 40 persen, supaya baterai tidak mengalami kerusakan dan memperpanjang usia baterai. Dengan lama penyinaran setiap hari minimal 3 jam sudah cukup untuk mengembalikan daya baterai yang terpakai dalam satu malam. Penggunaan listrik difokuskan hanya untuk penerangan dan televisi. Jika ingin menambah peralatan listrik lainnya seperti lemari pendingin, maka harus menambahkan peralatan panel surya, baterai dan inverter. Pada Tabel 3 tampak daya yang tersisa pada baterai setelah beberapa jam pemakaian.

Tabel 3. Tabel daya yang tersisa pada baterai

\begin{tabular}{|c|c|c|c|}
\hline Kapasitas AKI 100\% & & 1200 & Watt/Jam \\
\hline Toleransi AKI (SOC) & 0.4 & 480 & Watt/Jam \\
\hline Pemakaian AKI (DOD) & 0.6 & 720 & Watt/Jam \\
\hline Pakai Aki 1 Jam & & 720 & Watt/Jam \\
\hline Pakai Aki 2 Jam & & 360 & Watt/Jam \\
\hline Pakai Aki 3 Jam & & 240 & Watt/Jam \\
\hline Pakai Aki 4 Jam & & 180 & Watt/Jam \\
\hline Pakai Aki 5 Jam & & 144 & Watt/Jam \\
\hline Pakai Aki 6 Jam & & 120 & Watt/Jam \\
\hline Pakai Aki 7 Jam & & 102.8571 & Watt/Jam \\
\hline Pakai Aki 8 Jam & & 90 & Watt/Jam \\
\hline Pakai Aki 9 Jam & & 80 & Watt/Jam \\
\hline Pakai Aki 10 Jam & & 72 & Watt/Jam \\
\hline Pakai Aki 11 Jam & & 65.45455 & Watt/Jam \\
\hline Pakai Aki 12 Jam & & 60 & Watt/Jam \\
\hline
\end{tabular}


ABDIMAS: Jurnal Pengabdian Masyarakat Universitas Merdeka Malang Volume 5, No 1, Maret 2020: 70-78

Untuk mendapatkan hasil yang maksimal dari penerimaan sinar matahari, maka sudut pasang panel harus benar benar mengarah kepada matahari. Dengan bantuan software PV-Solar Power System untuk lokasi tersebut didapatkan sudut kemiringan 290 menghadap arah barat dan diputuskan untuk meletakkan panel PV tersebut pada bagian atas gedung pusat informasi Suku Anak Dalam, seperti ditampilkan pada Gambar 3 adalah software PV-Solar Power System dan hasil penghitungan sudut panel terhadap arah matahari.

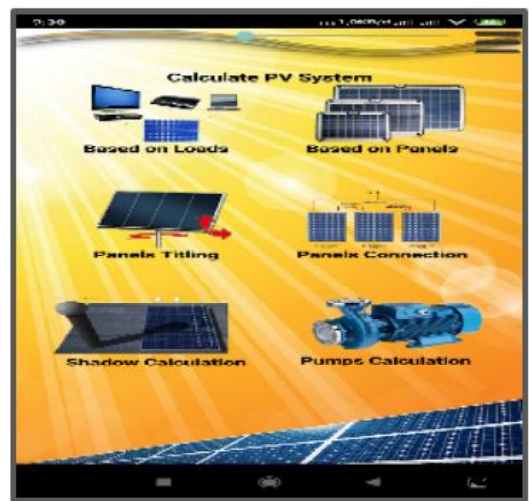

Gambar 4. Peletakan panel surya di atas Gedung Pusat Informasi Suku Anak Dalam

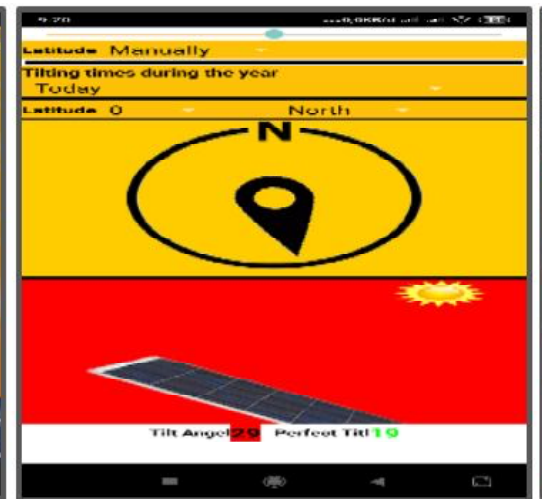

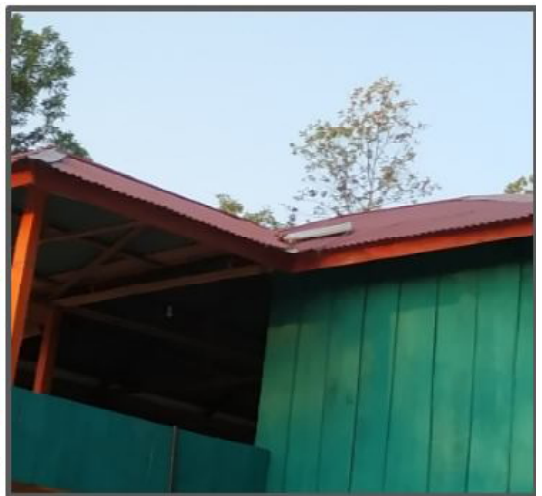

Gambar 3.

Software PV-SolarPower System

Syarat lain yang harus di penuhi untuk mendapatkan sinar matahari yang optimum adalah panel tersebut tidak terhalang oleh bayangan benda disekitar panel, seperti bayangan pohon atau dedaunan yang gugur menutupi panel surya tersebut. Gambar 4 adalah peletakan panel surya Gedung Pusat Informasi Suku Anak Dalam.

Kegiatan saat instalasi Panel surya seperti tampak pada gambar 5 sebelum dipasang di atap gedung dalam kegiatan tampak semua aktifitas dilakukan oleh pemuda desa tersebut. Dan instalasi solar charge controller jenis MPPT seperti pada Gambar 6. Solar charge ini memiliki keunggulan dibandingkan Tipe PWM yaitu efisiensi yang cukup baik untuk menyalurkan daya ke baterai.

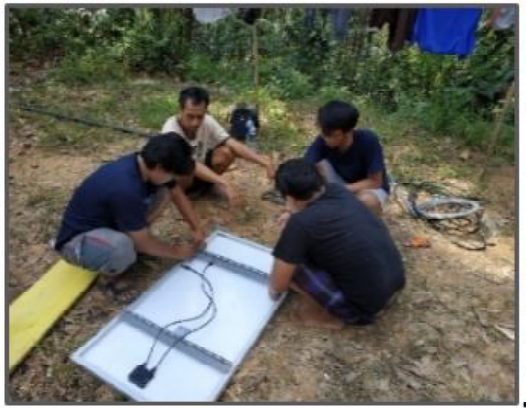

Gambar 5. Pemasangan Panel Surya
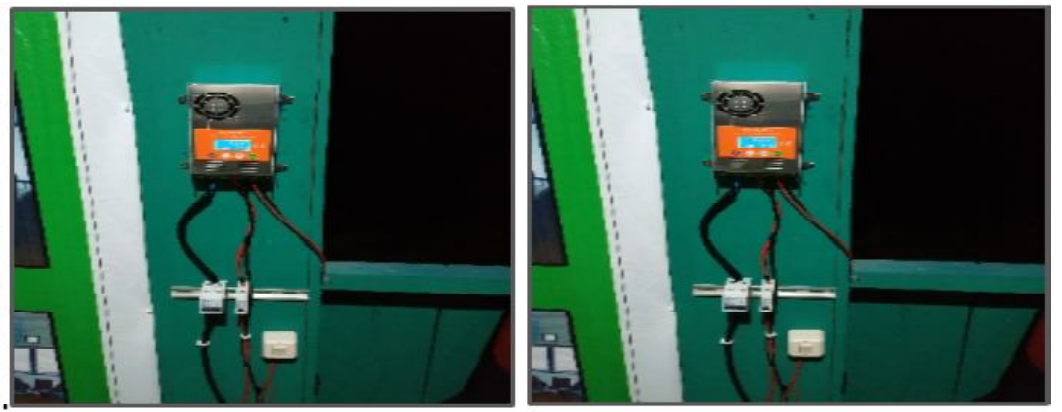

Gambar 6. Pemasangan Solar Charge controller beserta instalasi kelistrikan untuk penerangan 


\section{Pengenalan dan Penerapan Pembangkit Listrik Tenaga Surya di Desa Muara Kilis Kabupaten Tebo Jambi}

Yani Prabowo, Suwasti Broto, Gunawan P. Utama, Grace Gata, Yuliazmi

Dilihat dari sisi nilai ekonomi, penggunaan bahan bakar minyak pada genset dengan daya $1000 \mathrm{w}$ dalam 1 malam menghabiskan 7 liter bahan bakar seharga Rp 70.000; jika dalam 1 bulan akan menghabiskan sebesar Rp 2.100.000;

Dengan pembelian paket panel surya beserta kelengkapan seharga $\mathrm{Rp} 5.800 .000$; sudah mencukupi kebutuhan listrik setiap hari. Dengan usia baterai mencapai 5 tahun dan 20 tahun untuk panel surya sesuai dengan masa garansi yang diberikan oleh produsen. Panel surya umumnya harus dibeli dalam satu paket, pembelian ini tentunya sangat mahal dan memberatkan. Hal ini bisa diatasi dengan membeli secara bersamaan melalui koperasi unit desa dan masyarakat dapat membayar melalui sistem angsuran untuk jangka waktu tertentu. Jika sebuah paket panel surya Rp 5.800 .000 dan sistem pembayaran yang dilakukan secara angsuran selama 36 bulan ditambah bunga koperasi sekitar 2 persen jadi 2 persen dari Rp5.800.000 adalah Rp116.000. Maka (Rp116.000+Rp5.800.000)/36 = Rp164.000.

\section{SIMPULAN DAN SARAN}

\section{Simpulan}

Kegiatan pengabdian pada masyarakat ini sudah berjalan dengan baik, hal tersebut terlihat dalam sosialisasi akhir. Para warga dapat melakukan instalasi dengan baik dan dapat menganalisa kebutuhan listrik yang akan digunakan selain itu dalam pemasangan panel sudah memahami peletakan panel sesuai rekomendasi dengan menggunakan software PV Power System. Pengunaan software tersebut sangat membantu dalam proses peletakan panel karena dapat mengetahui sudut arah yang tepat dan jika diimplementasi sesuai dengan kondisi yang ada dilapangan. Kemudian mengenai teknik instalasi sudah berjalan dengan baik, para warga memahami teknik menyambung kabel dan pemilihan kabel yang sesuai dengan beban yang akan digunakan, sehingga dengan kemampuan instalasi yang baik dapat diterapkan untuk berbagai lingkungan. Dengan menggunakan pembangkit listrik tenaga surya dapat mengurangi pengeluaran masyarakat untuk mendapatkan energi listrik. Penggunaan BBM untuk genset dalam satu bulan menghabiskan Rp 2.400.00. Sedangkan untuk membangun PLTS mengeluarkan biaya Rp5.800.000; Investasi PLTS memang terasa mahal diawal tetapi selanjutnya tidak memerlukan biaya untuk operasional dalam jangka panjang. Pembelian Panel surya sebaiknya yang memiliki garansi untuk jaminan produk yang baik.

\section{Saran}

Rekomendasi untuk masyarakat pembelian paket panel surya cukup mahal diawal tetapi bisa diatasi dengan pembelian secara kolektif melalui koperasi desa dan pembayaran bisa dengan cara melakukan angsuran. Rekomendasi untuk kegiatan pengabdian masyarakat selanjutnya di lokasi ini perlu digali lebih dalam mengenai sumber daya alam yang ada pada lingkungan tersebut sesuai dengan kondisi alamnya.

\section{DAFTAR PUSTAKA}

Alfanz, R., Maulana, F., \& Haryanto, H. (2015). Rancang bangun penyedia energi listrik tenaga hibrida (PLTS- PLTB-PLN) untuk membantu pasokan listrik rumah tinggal. Setrum, 4(2), 34-42.

Diantari, R. A., Erlina, \& Widyastuti, C. (2017). Studi penyimpanan energi pada baterai PLTS. Energi \& Kelistrikan, 9(2), 120-125. https://doi.org/10.33322/energi.v9i2.48 
ABDIMAS: Jurnal Pengabdian Masyarakat Universitas Merdeka Malang Volume 5, No 1, Maret 2020: 70-78

Kumara, N. S. (2010). Pembangkit listrik tenaga surya skala rumah tangga urban dan ketersediaannya di Indonesia. Teknologi Elektro, 9(1).

Musyahar, G. (2019). Perbandingan penggunaan PLTS dengan genset di Desa Soko Kembang Kecamatan Petungkriyono Kabupaten Pekalongan. Elektronika dan Komputer, 12(1), 4245.

Pangestuningtyas, D. L., Hermawan, H., \& Karnoto, K. (2014). Analisis pengaruh sudut kemiringan panel surya terhadap radiasi matahari yang diterima oleh panel surya tipe larik tetap. Transient: Jurnal IImiah Teknik Elektro, 2(4), 930-937. https://doi.org/10.14710/transient.2.4.930-937

Purwoto, B. H., Jatmiko, Alimul, M., \& Huda, I. F. (2017). Efisiensi penggunaan panel surya sebagai sumber energi alternatif. Emitor, 18(1), 10-42. https://doi.org/10.23917/emitor.v18i01.6251

Rif'an, M., Pramono, S. H., Shidiq, M., Yuwono, R., Suyono, H., \& Suhartati, F. (2012). Optimasi pemanfaatan energi listrik tenaga matahari di Jurusan Teknik Elektro Universitas Brawijaya. Jurnal EECCIS, 6(1), 44-48.

Ruby, T., Yusman, M., \& Aziz, D. (2008) Deskripsi dan optimisasi model pembangkit listrik sistem hibrid menggunakan Teknik Control Parametrization Enhancing Transform (CPET). Jurnal Sains MIPA, 14(1), 33-40.

Suriadi \& Syukri, M. (2010). Perencanaan Pembangkit Listrik Tenaga Surya (PLTS) Terpadu menggunakan software PVSYST pada komplek perumahan di Banda Aceh. Jurnal Rekayasa Elektrika, 9(2), 77-80.

Tamimi, S., Indrasari, W., \& Iswanto, B. H. (2016). Optimasi sudut kemiringan panel surya pada prototipe sistem penjejak matahari aktif. Prosiding Seminar Nasional Fisika (E-Journal), 5, SNF2016-CIP. https://doi.org/10.21009/0305020111

Widodo, D. A., Suryono, Tatyantoro, \& Tugino (2010). Pemberdayaan Energi Matahari sebagai Energi Listrik Lampu Pengatur Lalu Lintas. Jurnal Sains dan Teknologi (Sainteknol), 8(2), 67-72. https://doi.org/10.15294/sainteknol.v8i2.324

Winardi, B., Nugroho, A., \& Dolphina, E. (2019). Perencanaan dan Analisis Ekonomi Pembangkit Listrik Tenaga Surya (PLTS) Terpusat untuk Desa Mandiri. Jurnal Tekno, 16(2), 1-11. https://doi.org/10.33557/jtekno.v16i1.603 